\title{
Does Continuity Allow For Emergence?
}

An Emergentist Reading Of Peirce's Evolutionary Thought

Maria Regina Brioschi

\section{OpenEdition}

\section{Journals}

Electronic version

URL: http://journals.openedition.org/ejpap/1647

DOI: $10.4000 /$ ejpap. 1647

ISSN: 2036-4091

Publisher

Associazione Pragma

Electronic reference

Maria Regina Brioschi, « Does Continuity Allow For Emergence? », European Journal of Pragmatism and American Philosophy [Online], XI-2 | 2019, Online since 24 December 2019, connection on 15 June 2020. URL : http://journals.openedition.org/ejpap/1647 ; DOI : https://doi.org/10.4000/ejpap.1647

This text was automatically generated on 15 June 2020 .

\section{(c)}

Author retains copyright and grants the European Journal of Pragmatism and American Philosophy right of first publication with the work simultaneously licensed under a Creative Commons AttributionNonCommercial-NoDerivatives 4.0 International License. 


\title{
Does Continuity Allow For Emergence?
}

\author{
An Emergentist Reading Of Peirce's Evolutionary Thought
}

Maria Regina Brioschi

\section{Emergence: The "Living Influence" of a Concept ${ }^{\star 1}$}

As many have remarked in the last two decades, the notion of "emergence" has been receiving renewed attention in various debates: from evolutionary biology to social sciences, as well as in cognitive sciences and philosophy of mind. ${ }^{2}$ Overall, this new interest can be related to the (supposed) explanatory function in complex systems studies and to the possibility of a "non-reductive physicalism" (Crane 2001: 207). As Bennett-Hunter has recently recalled:

In the broadest possible terms, the concept of emergence is supposed to describe what happens when systems reach a certain level of complexity, at which point 'new' properties or entities are said to emerge. [...] On the one hand, there has to be an important connection between the system, from which the phenomena [properties or entities] ${ }^{3}$ emerge, and the phenomena themselves. On the other hand, however, in order to count as emergent, phenomena have also to be novel with respect to the system out of which they supposedly emerge. (Bennett-Hunter 2015: 305)

Accordingly, the notion of "emergence" has been adopted as a keystone of "nonreductive physicalism," since it enables to disclose a "via media between the extremes of radical dualism and reductionism," according to Timothy O'Connor. The author continues:

This middle road consists in the claim that the phenomenon in question is at once grounded in and yet emergent from the underlying material structure with which it is associated. At various times, this claim has been made with respect to the socalled secondary qualities, biological life, and, most commonly of all, consciousness. (O'Connor 1994: 91)

Although it is possible to point to the two general features of the concept of emergence listed above, there is no common definition or definite meaning of it, nor is there a 
specific correspondence in the usage of the concept among different scholars and disciplines. Indeed, one of the main problems related to current debates on emergence is how to find a coherent framework in which to develop research.

To unravel this tangled situation, some distinctions have been made that are useful for ordering problems generally involved in emergentism. Among them, two distinctions stand out and are nowadays generally accepted and assumed in contemporary debates. The first is the difference between an epistemological and an ontological concept of emergence (and emergent phenomena), and the second is between a weak and a strong sense of emergence. ${ }^{4}$ The first distinction depends on the answer given to the following question: "Is emergence an objective feature of the world or is it merely in the eye of the beholder?" ${ }^{5}$ Accordingly, from an epistemological perspective "emergence" refers to a category characterizing our models of representation or theories of nature and, as a consequence, can even be construed as an effect of our limited patterns of knowledge. On the contrary, from an ontological viewpoint, "emergence" denotes the real occurrence of some "qualitative novelty." Consequently, the emergent phenomena ${ }^{7}$ are considered as real components of the world, irreducible to the prior level from which they appear.

The second distinction (between weak and strong emergence), suggested first by Mark A. Bedau in 1997, ${ }^{8}$ and revisited and further expanded by David Chalmers in 2006, can be expressed as follows: we speak of a weak emergent phenomenon when "the high-level phenomenon arises from the low-level domain, but truths concerning that phenomenon are unexpected given the principles governing the low-level domain," while we detect a strong emergent phenomenon when "the high-level phenomenon arises from the low-level domain, but truths concerning that phenomenon are not deducible even in principle from truths in the low-level domain" (Chalmers 2006: 244; italics mine). Thus, weak emergent phenomena are unexpected and unpredictable, yet deducible from the low-level domain's laws. Their unpredictability lies indeed in the fact that, although at the high-level any global/complex behavior is constituted by/ reducible to the low-level domain, these low-level interactions are intertwined in such a complex structure that it makes impossible a "simple" explanation of high-level phenomena, and therefore their predictability. This notion of "weak emergence" is usually adopted in the description of complex systems, while the notion of "strong emergence" is used in philosophical contexts. The most notable phenomenon to which it has been applied is that of consciousness.

To sum up the main claims distinctive of the strong emergentist approach, which are also indicative of the problems implied by it, we can adopt Jeagwon Kim's overview, slightly modified in accordance to the forehand. ${ }^{9}$ Thus, on the whole, we can summarize Emergentism as a doctrine based on:

1. Systemic perspective. The emergence of complex higher-level phenomena (proper ontological entities and/or new structural configurations with a high-level of complexity, from the coming together of the low-levels entities; and/or emergent properties not consequent from those of the prior, lower-levels) - W \& S emergence;

2. Unpredictability. An essential feature is the unpredictability of emergent phenomena (a phenomenon can be called "emergent" if and only if the information, properties and laws of the low-level cannot predict it in principle) - W \& S emergence;

3. Unexplainability and irreducibility of emergent phenomena. The emergent phenomena cannot be epistemologically explained in terms of their low-level domains, nor 
ontologically reducible to them - S emergence only;

4. Downward causation. The emergent phenomena are not only irreducible to lower levels, but exercise their own causal powers both at their level and further down on their lower, constituent levels - S emergence only.

Far from an exhaustive account of emergentism, these features are useful as pins to stick into the map of emergentism in order to orient ourselves in current and past debates. Furthermore, it has recently been pointed out how the most controversial, as well as the most crucial, points to clarify, in order to make theories of emergence stronger, is a "positive characterization of emergence." Namely, a characterization that offers an explanation of "irreducibility" and also of "downward" causation (cf. Kim 1999; cf. points 3, 4). Many lines of investigation can be pursued to clarify these issues; in this paper I will adopt both a historical and philosophical-critical perspective. A historical one because British Emergentism is usually interpreted as the first exposition of a strong notion of emergence (cf. Chalmers 2006: 244). This direction has even been advocated in current debates, as Kim states: "Any account of emergence, I believe, should show significant continuity with the concept that the British emergentists of the early 20th Century, such as Alexander, Morgan, and Broad, had in mind [...]." (Kim 2006: 548). And a philosophical-critical one because a reconstruction of some key concepts of British Emergentism, combined with classical pragmatists' approaches and issues (Peirce's in particular), can lead to an elucidation of the philosophical problems related to both a positive description of emergence and downward causation.

\section{From Emergentism to Pragmatism and back}

\subsection{Historical Examination}

"British Emergentism" is the label usually applied to three British philosophers of the early 20th Century who built their systems of thought upon the notion of "emergence," thereby denoting the dynamical relationship of the different layers of reality: Conwy Lloyd Morgan (1852-1936), Samuel Alexander (1859-1838), and Charlie Dunbar Broad (1887-1971). ${ }^{10}$ With their major works, Alexander's Space, Time and Deity (1920), Lloyd Morgan's Emergent Evolution (1923), and Broad's The Mind and its Place in Nature (1925), each tried to "offer an alternative to mechanism and vitalism by introducing a third theory called emergentism" (Stephan 1992: 25), based upon the following assumptions (cf. McLaughlin 1992: 49-51): (a) everything is made of matter (i.e., elementary material particles); (b) these particles are organized in levels hierarchically ordered on the basis of their complexity, and to each of them corresponds a special science (in order: to the physical level/Physics, to the chemical level/Chemistry, to the biological level/Biology and the psychological level/Psychology); (c) each level is made up of the lower ones, though its properties are not reducible to them (a certain structural configuration indeed implies certain specific causal powers/laws different from level to level); (d) those "emergent laws" also have an impact on the lower levels, with what has been called downward causation. Their common efforts were so successful that from the 1920 s to the 1960s philosophical debates on emergentism notably multiplied, and the category of emergence became widespread, largely adopted, or at least discussed. ${ }^{11}$

As the chronology clearly indicates, Peirce could not have read those works during his life. And, although Lloyd Morgan was invited to give lessons in Boston, New York and 
Chicago in 1895-1896, there is no indication that Peirce knew him or his studies, which were mainly devoted to comparative psychology before the formulation of his emergentist theory. As further evidence of Peirce's lack of connections with emergentism - Goudge highlighted in 1973 - Peirce never adopts the notion of "emergence" or "emergent" in a technical manner in his writings (Goudge 1973: 144). On the contrary, as it is well known, John Dewey and especially George Herbert Mead used the notion of emergence, and, for this reason, their thoughts have often been considered as "emergentist" or at least comparable to those theories (cf. Blitz 1992; Stephan 1999; El-Hani \& Pihlström 2002; Cherlin 2015). ${ }^{12}$ Before examining in detail the extent to which classical pragmatists considered British Emergentism, it is worthwhile to note that Lloyd Morgan, Alexander and Broad never looked at pragmatism as a significant source of ideas, nor as a benchmark for developing their thoughts. On the whole, they never took into account pragmatism as a philosophical movement, but all of them held in great esteem the work of William James, especially as a psychologist. ${ }^{13}$

If we then move on to the historical reconstruction of pragmatists' connections to emergentism, ${ }^{14}$ the key figures who explicitly took into account emergentism are Ferdinand C. S. Schiller, John Dewey, and especially George H. Mead. Indeed, the three of them either adopt an "emergentist" terminology in their writings, or took part in emergentism's debates, though not in a univocal sense. For instance, in Experience and Nature Dewey evaluates his own account of life and the mind-body problem as "an attempt to contribute to what has come to be called an 'emergent' theory of mind" (Dewey 1925: 271); Schiller carefully scrutinizes the concept of "emergence" in his essay "Creation, Emergence, Novelty" (1930), ${ }^{15}$ and, in a more crucial way, Mead adopts the concept of emergence as pivotal in his The Philosophy of the Present, underlying the social character of the self, its relation to language, and the connection of the present to the past. In the "Introduction" of this posthumous book, Arthur E. Murphy mentions emergentism as a primary source of Mead's thought. He states:

The third and perhaps the dominant strain in these lectures, however, is derived neither from pragmatism nor from research science, but forms part of that philosophy of nature which will no doubt be regarded as the characteristic contribution of the 1920's in Anglo-American philosophy. Alexander's Space, Time and Deity was the pioneer work in this transition from problems of knowledge - of "realism," "pragmatism" and "subjectivism" - to speculations about space and time and finally to metaphysics and the categories. (Murphy 1932: xiv; italics mine) ${ }^{16}$

A few pages later John Dewey, in the Prefatory Remarks, makes a very helpful comment both from a historical perspective and a theoretical one:

Since his problem was (and that long before the words "emergent evolution" were heard), essentially that of the emergence of the new and its ultimate incorporation in a recognized and now old world, one can appreciate how much more fundamentally he took the doctrine of emergence than have most of those who have played with the idea. (Dewey 1932: xxxviii)

What Dewey wants to stress here is the originality of Mead's thought, but he also enlightens two fundamental aspects of our brief historical reconstruction of Classical Pragmatism and British Emergentism. 1) During the twenties, especially in the AngloAmerican areas, debates on emergence and the emergentist "vocabulary" were so widely diffused that Murphy defines the notion of "emergence" as a "catchword" of the period (Murphy 1932: xi). Accordingly, the pragmatists who lived in that period compared their thoughts with this "emergent" mainstream, critically evaluated its notions, and sometimes adopted its jargon as well, as was the case for Mead, albeit with 
some modifications. 2) According to Dewey, one of the core topics of emergentism (the emergence of the new and its encounter with the old) can be traced in Mead's thought long before it became preeminent in British Emergentism, and this - together with Schiller's criticism of emergence - leads us toward a more theoretical consideration of the connections of emergentism and pragmatism. Accordingly, in the next paragraph I will try to develop the hypothesis, suggested by Dewey's quote, that Classical Pragmatists and British Emergentists can be viewed as two different, possible answers to the same range of problems and issues inherited from the past and especially developed by British thinkers.

\subsection{Theoretical Examination}

\subsubsection{Common Traits}

Overall, the main reason why Dewey and Mead have been often compared to or considered together with British Emergentists lies on the latters' non-reductive materialism. ${ }^{17}$ As Kim states:

Classical emergentists like Morgan and Alexander thought of themselves as occupying a moderate intermediate position between the extremes of "mechanistic" reductionism on the one hand and explicit dualisms like Cartesianism and neo-vitalism on the other. [...] It is evident that emergentism is a form of what is now standardly called "non-reductive materialism," a doctrine that aspires to position itself as a compromise between physicalist reductionism and allout dualisms. (Kim 1999: 4)

And the same intermediate position can also be advocated for Classical pragmatists, considering their strong opposition to any dualism or Cartesianism and their consequent, radical understanding of mind and matter. As Dewey's reflection testifies to: "There is neither a sudden jump from the merely organic to the intellectual, nor is there complete assimilation of the latter to primitive modes of the former" (Dewey 1930: 220). ${ }^{18}$ More in detail, we can identify two key-concepts associated to both classical pragmatism and British Emergentism:

(a) Mind in Evolution. Classical pragmatists intersect the line of thought of emergentism at the very point where emergentism is extremely appealing still today: the mind-body problem. ${ }^{19}$ They are indeed among the first who tried to philosophically re-think mind in an evolutionary framework, in continuity with the organic world but without denying its specificity or reducing its laws to the previous ones. In this regard, Goudge noticed in 1973:

The pragmatists were the first group of philosophers to work out in detail a philosophy of mind based on evolutionary principles. Moreover, since they were familiar with classical ideas in the field, they were able to assess the kinds of changes in those ideas which evolutionary principles required. (Goudge 1973: 133)

Similarly, British Emergentism comes from an evolutionary background. ${ }^{20}$ With their "emergent" view of evolution, they try to preserve the continuity/discontinuity between levels: inorganic/organic, organic/psychical, etc. In Lloyd Morgan's own words:

Evolution, in the broad sense of the world, is the name we give to the comprehensive plan of sequence in all natural events.

But the orderly sequence, historically viewed, appears to present, from time to time, something genuinely new. Under what I here call emergent evolution, stress is laid on this incoming of the new. (Lloyd Morgan 1923: 1; italics mine) 
This emphasis on the concept of the incoming of the new, and more generally the philosophical question of how to think the relationship between continuity and discontinuity, it is not only confined to the emergence of mind, but represents a categorical and metaphysical problem per se.

(b) Novelty. This general problem of "the incoming of the new," so fundamental for British Emergentism, can be viewed as primary also for pragmatism, so that it can count as the second common trait. If I have already stressed (cf. the previous paragraph) the importance of "novelty" for Mead through Dewey's words, consider also Schiller's Presidential Address of the Aristotelian Society of 1921, which is almost entirely devoted to the philosophical problem of novelty; ${ }^{21}$ or, even before, James's posthumous book Some Problems of Philosophy, whose last five chapters were dedicated to novelty (James 1911: 147-220). ${ }^{22}$

For his part, Dewey also adopts the word "novelty" - whose use is so rare in both ordinary English and "philosophical" English to be considered almost a technicality - in his books. He defines it as the "emergence of unexpected and unpredictable combinations" (Dewey 1925: 281), in a sense perfectly coincident with the emergentist meaning of the word. Accordingly, if the conception of mind in evolution is the most relevant and specific issue that emergentism and classical pragmatism have in common, the relevance of novelty and the occurrence of the new is the more general trait they share. Indeed, the emergence of mind is circumscribed in this antimechanistic view of evolution that more generally gives room to development and change, and especially to irreducible novelty.

\subsubsection{Pragmatism's Criticism of Emergentism}

All the same, Dewey and Schiller were not fully satisfied with the concept of emergence, as El-Hani and Pihlström have underlined, nor can we say that classical pragmatists' claims can be fully identified with those of emergentism. ${ }^{23}$ On the whole, the classical pragmatists' critiques can be abridged in a recent quote by another famous, contemporary pragmatist, Hilary Putnam. With reference to consciousness, in 1999 he spoke of emergence as a "bad metaphor":

It is a bad metaphor because it suggests that all the true statements expressible in the vocabulary of the "basic" sciences of physics, chemistry, biology [...] might have been true without there being consciousness or intentionality. In short, it suggests that we might conceivably have all been Automatic Sweethearts, and that it is "mysterious" that we aren't. (Putnam 1999: 174)

Also from a classical, pragmatist viewpoint we can say: (a) on the one hand that it is "a bad metaphor" because of the "magical" tone that ultimately retains the idea of "emergence" (cf. also Dewey, Bentley 1949 [1989]: 45, 121), ${ }^{24}$ so that it becomes a way of "blocking the way of inquiry," to quote Peirce's famous motto, on issues so fundamental as the mind-body relation; (b) on the other hand, "emergence" is "a bad metaphor" because it assumes that the primary level of reality is always there, independent from us, "ready-made," undisputed, and uncritically accepted (cf. in this regard, Schiller 1930: 32). This second aspect has many metaphysical and ontological facets. For instance, as Pihlström pinpointed (Pilhström 2002: 155), it implies the whole debate of realism, which is the controversy of the universals (and accordingly the status of properties). To put it shortly, we could ask: what ontological scheme can be adopted to justify and explain something like an emergent property? Or - with reference to the 
more limited issue considered in the present paper - what categories should we assume in order to think an "emergent evolution"? On those answers depends also the prospect of solution or the clarification of the problem of downward causation, which we saw in $\$ 1$ is still today one of the most problematic aspects of emergentism. Furthermore, we know that pragmatic realism is at once "an inherently pluralistic and antireductionistic position" (El-Hani \& Pihlström 2002: 24), and - as is especially the case for Peirce's pragmaticism - a continuistic standpoint.

\section{Missed Connections and Common Roots: British Emergentism and Peirce}

If we now restrict our analyses to Peirce, at first glance it seems difficult to make a comparison. As it has been recalled in \$2.1, Peirce could not be a witness to the flourishing of British Emergentism. On what elements, then, does it make sense to speak of an "emergentist" reading of Peirce? For the sake of clarity, I will develop my investigation in two different perspectives, as I did in the previous paragraph more generally: the first is more critical-historical, while the second is more theoreticalspeculative. Indeed, although there is no apparent connections between Charles Sanders Peirce and British Emergentists, they have many common roots.

\subsection{A Matter of "British" Influence}

Some scholars trace back "emergentism" to Ancient Greek thought and especially to Aristotle (cf. Caston 1997). Nonetheless, limiting the present investigation to the development of an "explicit" emergentist thought, it is worthwhile to note that Emergentism of the twenties has its own roots in British thought. As McLaughlin clearly indicates:

This tradition [of British Emergentism] began in the middle of the nineteenth century and flourished in the first quarter of this century. It began with John Stuart Mill's System of Logic (1843), and traced through Alexander Bain's Logic (1870), George Henry Lewes's Problems of Life and Mind (1875). (McLaughlin 1992: 49)

Thus, the reason why McLaughlin indicated John Stuart Mill, Bain and Lewes as the fathers of emergentism is not merely a matter of historical reconstruction. Although none of them would call themself "emergentist," they are mentioned in the works of British Emergentists as the first thinkers of the notion of "emergence." For instance, consider the beginning of Lloyd Morgan's Emergent evolution: ${ }^{25}$

The concept of emergence was dealt with (to go no further back) by J. S. Mill in his Logic (Bk. III, Ch. vi, \$2) under the discussion of "heteropathic laws" in causation. The word "emergent," as contrasted with "resultant," was suggested by G. H. Lewes in his Problems of Life and Mind (Vol. II, Prob. V, Ch. iii, p. 412). Both adduce examples from chemistry and from physiology; both deal with properties; both distinguish those properties (a) which are additive and subtractive only, and predictable, from those (b) which are new and unpredictable; both insist on the claim that the latter no less than the former fall under the rubric of universal causation. (Morgan Lloyd 1923: 2-3)

If we then turn to C. S. Peirce, the role played by all those authors in the development of his pragmatism is well known, ${ }^{26}$ and it is worthwhile to note that none of those authors, neither Stuart Mill, nor Bain, nor Lewes, had technical training in biology or 
natural sciences. Peirce refers to them as logicians. Their primary concern and field of research was indeed that of logic, which was also of supreme interest for Peirce. Besides, it is not a coincidence that British Emergentism (cf. the above quotation by Lloyd Morgan) is not based so much on biological evidence. Rather it addresses the issue of the logic of the universe, and it seeks new conceptions, such as that of emergence, or a logical framework, in which both continuity and novelty can be admitted at once. Only in this way it is indeed possible to gain a new idea of the relationship between different realms of reality, one that works scientifically and is able to explain all natural phenomena, mind included.

To enlighten the logical side of emergent evolution might sound curious today, but this association between logic and evolutionary theories was not uncommon at all during the 19th century and the early decades of the 20th century. It is sufficient to remember on the one hand that, as stated before, Lloyd Morgan borrowed the idea of emergence from Stuart Mill's System of Logic, and, on the other hand, Peirce's "logical" appraisal of Darwin. To shed more light on the latter aspect, which has not yet been investigated, I will now analyze what can be considered the second common root of British Emergentism and Peirce: the evolutionary thought of Charles Darwin and Herbert Spencer.

\subsection{For a "Thorough-going Evolutionism": with Darwin beyond Spencer}

Generally speaking, British Emergentism can be located in between Darwin's and Spencer's theories. As Peter A. Corning summarizes:

Many theorists of that era viewed Darwin's explanation as unsatisfactory, or at least incomplete, and emergent evolution theory was advanced as a way to reconcile Darwin's gradualism with the appearance of qualitative novelties and, equally important, with Herbert Spencer's notion (following Lamarck) of an inherent, energy-driven trend in evolution toward new levels of organization. (Corning 2012: $297-8)^{27}$

This notion of an "energy-driven trend in evolution," as we will see in $§ 4$, is also a feature characterizing Peirce's evolutionary thought. But the first aspect mentioned in the quoted passage should be not overlooked. Indeed, on the one hand, British Emergentism tried to "correct" Darwin's gradualism with Spencer's "energy-trend in evolution towards new level of organization," and, on the other hand, to state that they combined Darwin's gradualism with the appearance of qualitative novelties means that they proposed and promoted a non-mechanistic view of evolution and the cosmos. Lloyd Morgan pointed it out clearly in the first chapter of Emergent evolution:

[...] the whole doctrine of emergentism is a continued protest against mechanical interpretation [...]. The essential feature of a mechanical - or, if it be preferred, a mechanistic - interpretation is that it is in terms of resultant effects only, calculable by algebraic summation. It ignores that something more that must be accepted as emergent. [...] Against such a mechanical interpretation - such a mechanistic dogma - emergent evolution rises in protest. The gist of its contention is that such interpretation is quite inadequate. Resultants there are; but there is emergence also. (Morgan Lloyd 1923: 7-8)

Accordingly, this anti-mechanistic feature makes British Emergentism stand out against Spencer. While taking the stance of Spencer in facing Bergson's objections to Spencer's "reductionism," Lloyd Morgan himself admits, in his 1913's "Herbert 
Spencer's lecture," that "Spencer tried to reduce all kinds of relatedness to one quasimechanical type; and he signally failed - or shall I say that he succeeded only by ignoring all the specific differences [...]" (Morgan Lloyd 1913: 18). As a consequence, British Emergentism of the early 20th century was strongly influenced and inspired both by Darwin's and Spencer's evolutionisms, but, all the same, plainly aimed at overcoming the limitations and weaknesses of the previous viewpoints. Again, overall Darwin's and Spencer's explanations seemed to lack an explanation for the incoming of the new in evolution.

Even Peirce can be construed as a "critical" appraiser of both Darwin and Spencer, insofar as he develops his own evolutionary thought as a radicalization and correction of their prominent and most common views of evolution. However, since the attention is usually focused only on their opposition (especially for Peirce vs. Darwin) by secondary literature, it is necessary to offer a more in-depth analysis on those comparisons than the one just offered for British Emergentism.

\subsubsection{Peirce and Darwin}

To investigate the connections between Peirce and evolutionary theories, his famous quote: "Philosophy requires thorough-going evolutionism or none" (W8: 102, 1890) immediately gives an idea of the fundamental relationship that, according to him, evolution and philosophy have in general and especially for Peirce's own philosophy. But to what extent is he actually referring to Darwin when speaking about evolutionism? In fact, Peirce explicitly says that "Everybody today is evolutionist. This is said to be the day of evolutionism" (NEM 4: 140; R 942, 1896).

First of all, the young Peirce, together with William James and others, but especially Chauncey Wright, ${ }^{28}$ discussed Darwin's The Origin of Species in "The Metaphysical Club" (1872). But it is notorious that Peirce had a quarrel with Wright on the general interpretation to attribute to Darwin's magnum opus. Furthermore, generally speaking, Peirce maintained a critical attitude towards Darwin, and this is probably due to the influence of Louis Agassiz - one of the most determined opponents of Darwin in America, as some scholars have shown (cf. Wiener 1949, Skagestad 1979). Often Peirce's evolutionism is promptly classified as neo-Lamarckian (cf. for instance Reynolds 2002: 99) and, for this reason, immediately set aside as an unsupported theory.

In the light of these preliminary remarks, at first glance Peirce's evolutionary theory might be interpreted as far-off, or even contrary, to Darwin's thought. Notwithstanding, in the passages where Peirce examines Darwin's very idea of evolution, the truth of the matter is quite the opposite. For instance, Peirce wrote in Design and Chance: "My opinion is only Darwinism analyzed, generalized, and brought into the realm of Ontology." (W4: 552, 1884). As a consequence, taking into account such a radical, clear-cut, and unambiguous statement, Peirce's debt to Darwin seems, at least provisionally, clear and forceful. Therefore, Peirce's evolutionary thought must have drawn inspiration from Darwin, and, as a consequence, according to my view all the differences between the two authors must be construed from within this perspective of influence and proximity. Let me first consider in detail - taking into account this unequivocal, programmatic purpose of Peirce (to analyze, generalize, and bring Darwinism into ontology) - the reasons why he esteemed Darwin, so far as to identify with Darwinism or even to propose to expand it into ontology. 
The first reason why Peirce was committed to Darwinism, the primary and most general one, is the relevance that Darwinism has for logic. As it was for emergentism, this assertion may sound paradoxical, but for Peirce to support evolutionism means in the first place to recognize the fundamental role that statistics, probability and fallibilism, play together in knowledge. Peirce states: "The Darwinian controversy is, in large part, a question of logic. Mr. Darwin proposed to apply the statistical method to biology." (W3: 244, 1877). Later, in The Architecture of Theories, Peirce once again emphasizes the relation of Darwinism, logic, and statistics, when he talks about the Darwinian principle and the law of large numbers. He affirms:

This Darwinian principle is plainly capable of great generalization. Wherever there are large numbers of objects, having a tendency to retain certain characters unaltered, this tendency, however, not being absolute but giving room for chance variations, then [...] there will be a gradual tendency to change in directions of departure from them. (W8: 102, 1890) ${ }^{29}$

Here we can detect the second fundamental reason why Peirce has a high esteem of Darwinism: the role preserved for chance or spontaneity in this system of thought. He stresses this feature, for instance in The Doctrine of Necessity Examined, as follows in regard to his evolutionary thought:

By thus admitting pure spontaneity or life as a character of the universe, acting always and everywhere though restrained within narrow bounds by law, producing infinitesimal departures from law continually, and great ones with infinite infrequency, I account for all the variety and diversity of the universe, in the only sense in which the really sui generis and new can be said to be accounted for. (W8: 122, 1891)

This general account of the universe as a place where spontaneity, chance, or novelty is acting "always and everywhere" belongs under the label of the doctrine of "tychism" or "tychasm" (from the Greek Túxๆ, chance), as Peirce calls it. ${ }^{30}$ This represents the keyconcept for a thorough-going evolutionism, that is, for an evolutionary thought that can also explain and encompass laws and their evolution, ${ }^{31}$ which is representative of Peirce's own thought. In this regard, too, he refers again to Darwin as a prominent source of inspiration:

It would seem [...] that through biological studies science may be led to modify the existing mechanical theory of the universe, which is not at all requisite to its progress, but is merely the coloring which scientific thought acquired during the period beginning with Galileo and ending with Helmholtz's great dynamical memoir, when mechanics and allied branches of physics were the chief subjects of thought, and which in the new period that opened with Darwin is already beginning to be corrected. Many biologists are pleading today for the admission of genuine spontaneity. (N1, 176)

To this extent, that is, to the acknowledgment of chance as a primary and essential component of the universe, Peirce and Darwin are allied and not in opposition at all. The differences between their understandings of the universe will especially emerge in the final essay of the The Monist series of the 1890s, Evolutionary love, ${ }^{32}$ and pivot around the rendering of the evolution of the universe and the role assumed by chance within it (cf. §4). However, their proximity gets even closer when we analyze Peirce's criticisms towards Spencer. 


\subsubsection{Peirce and Spencer}

Peirce's quarrel with Herbert Spencer, and more generally with the doctrine of necessity or Necessitarianism, began in 1887 (cf. W6: 61-4) and continues until the end of his life. It is connected to the reason why Peirce appreciates Darwin's very idea of evolution and concerns Spencer's mechanical view of the universe. It is indeed the same reason why Peirce charges Spencer for not being a thorough-going evolutionist, or - in other words - radical enough in his evolutionism.

For Peirce the difference between his evolutionary standpoint and Spencer lies in the fact that the latter restricts "evolution to certain elements of the universe, and gives it a merely secondary position as a corollary of physical law of the "persistence of force', thus making that law something absolutely inexplicable and inscrutable [...]." (NEM 4: 141, R 942, 1896). On the contrary, for Peirce laws are not absolute or inexplicable: every existent element of the universe must be evolved, and we can investigate their evolution. In a nutshell, for Peirce natural laws are historical products that are liable to evolution..$^{33}$ As he remarks in The Architecture of Theories: the laws of nature are "results of evolution. This supposes them not to be absolute, not to be obeyed precisely. It makes an element of indeterminacy, spontaneity, or absolute chance in nature." (W8: $101,1890)$. Not only must we admit "an element of indeterminacy" in nature to account for them, but this element of indeterminacy is in fact the only one that can account for growth and diversification. Indeed, how could a mechanical law produce diversification, variety, and heterogeneity ${ }^{34}$

Accordingly, after the historical reconstruction of the relationships of influence and divergence carried out in this paragraph, we can infer that, although Peirce was not familiar with British Emergentists, he shares with most of them a great acquaintance with the British logicians of the 20th century, who first came up with the concept of "emergence." He also shares with them a very similar awareness and perception of the path opened by Darwinism - its great potentiality, as well as its limits and further developments. On the basis of those similarities and shared concerns, I will offer in the last part of this article an emergentist reading of Peirce's evolutionary thought, not in the sense of reducing Peirce to British Emergentism or vice-versa, but providing a line of interpretation of Peirce's evolutionary thought that is compatible with an emergentist viewpoint, or at least alternative to it. In other words, I will show how Peirce's evolutionary thought offers a valid response to the same problems that emergentism tries to address and answer.

\section{An "Emergentist" Reading of Peirce's Evolutionary Thought}

Although Thomas A. Goudge, in his 1973 pioneering study on pragmatism and the evolutionary view of mind, set aside Peirce by simply stating that he "gives priority of continuity" and "does not introduce the idea of emergence at all, but rather employs the idea of 'pure spontaneity"' (Goudge 1973: 144), the hints of emergentism in Peirce's thought, as well as the feasibility of comparison between his pragmaticism and British Emergentism, have recently been supported by many scholars. Among them, the first who has noted Peirce's and emergentism's proximity is Ian Hacking, who states in reference to The Monist series of the 90s that Peirce puts "emergentism together with 
ideas of statistical mechanics, to form a new and vigorous indeterminism" (Hacking 1983: 468). From that time onwards, comparative studies have been increasing, especially in the last decades. Among others, see for instance Claudine Tiercelin's comparison between the irreducibility of higher-level properties and the irreducibility of Thirdness (Tiercelin 1998: 13-8), or - more recently - Queiroz's and El Hani's article on "Semiosis as an Emergent Process" (Queiroz \& El Hani 2006). Furthermore, even more relevant with regard to the present article, since I focus on the concept of emergent evolution, ${ }^{35}$ see Philip Rose's essay on "C. S. Peirce's Cosmogonic Philosophy of Emergent Evolution" (Rose 2016), where a detailed, emergentist analysis of Peirce's development of the universe from its very beginning is carried out with success. I will now provide an emergentist reading of Peirce's evolutionary thought that is not based on his cosmogony, but rather on his categorical cosmology (that is, on his universal categories that the author uses to describe all the features of the universe) and his own "emergentist" understanding of the dynamics of evolution, which characterizes the universe at large and is still operating today.

\subsection{The Place of Novelty in Peirce's Universe}

In paragraph \$2.2.1. it has already been underlined that the pivotal topic for British Emergentism is to allow the occurrence of novelty in an evolutionary framework, and that the very concept of emergence addresses this issue exactly. Furthermore, in paragraph \$3.2.1., it is apparent from the comparison between Peirce and Darwin that Peirce strongly claimed a place for novelty in the universe, under the label of chance or spontaneity. But what is the relevance of such a novelty within Peirce's own philosophy? And how did he conceive it?

To answer this question, the first point to mark is that according to Peirce speaking of chance does not mean a return to some sort of vitalism. For him chance represents a way of appealing to novelty via statistics and also probability. As Peirce himself specifies in 1898 (The Logic of Continuity, Reasoning and the Logic of Things), "When I speak of chance, I only employ a mathematical term to express with accuracy the characteristics of freedom or spontaneity" (RLT: 261, 1898). The reasons why he insists that novelty, as chance, must be admitted into any account of the universe are summarized in four "positive arguments": (a) the prevalence of growth as opposed to the conservation of energy; (b) the variety present in the universe; (c) feeling; and (d) the explanation of law (cf. §3.2.2.) (CP: 6.613, 1893).

Taking into account the role assigned by Peirce to chance, and that Darwinism is a kind of tychism (cf. \$3.2.1.) - that is, an evolution by chance - we could tend to think that Peirce's evolutionary hypothesis is that of tychism too. However, even if Peirce continues to insist until the end of his life on chance as a real factor of the universe (cf. R 200, CP 6.322, c. 1908), his standpoint is more elaborated, because he explicitly refuses the label of "tychism" or "tychasm" for his own philosophy. Thus, in order to understand better his own position as favorable to chance but not reducible to tychism, it can be helpful to follow again the comparison with Darwin to see where Peirce's view diverges.

Indeed, although the year before, in The Architecture of Theories, Peirce's interpretation of Darwinism was quite generous, in Evolutionary Love he considers Darwin only to the extent that the latter represents an eminent instance of a certain egoistic, political- 
economical perspective, which Peirce believes is dominant in the 19th century. In this sense, Peirce states that [Darwin's] hypothesis was "without dispute one of the most ingenious and pretty ever devised," "but the extraordinarily favorable reception it met with was [...] because of the encouragement it gave to the greed-philosophy" (W8: 191, 1982). ${ }^{36}$ In this regard, the point he criticized the most was that of natural selection, conceived of "the survival of the fittest." ${ }^{37}$ But the other reason - a more general one why Peirce dissociates himself from Darwin in this article is that he clearly rejects what he calls tychasm, or - better yet - tychastic evolution, that is, evolution by fortuitous variation, or chance.

But how is that possible, given the relevance Peirce attributes to chance? In the answer to this question lies the great affinity of Peirce and British Emergentism. But, to understand this apparently shift of mind with regard to Darwin, I must first introduce and briefly touch upon the three possible modes of evolution that Peirce pointed out in Evolutionary Love. ${ }^{38}$

\subsection{Emergence as Novelty in Evolution: Evolutionary Love}

According to Peirce we can detect three different kinds of evolution: tychastic

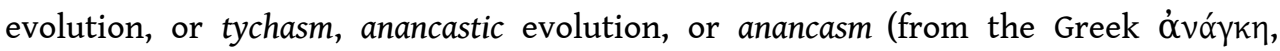
necessity), and agapastic evolution or agapasm (from the Greek ơ үớ Roughly speaking, the first is evolution "by fortuitous variation," the second is evolution by "mechanical necessity," and the third is evolution by what he calls "creative love" (W8: 194). The correspondence is apparent between those three kinds and Peirce's three categories, or - as he defines them - his three "important metaphysico-cosmical elements" (EP2: 164, 1903). Namely, Firstness (that stands for chance, spontaneity, freedom), Secondness (referring to reaction, brute facts), and Thirdness (that stands for the category of habits and continuity). Peirce himself affirms that agapasm "is the sort of evolution which every careful student of my essay "The Law of Mind" must see that synechism calls for" (W8: 186). ${ }^{39}$

More in detail, tychastic evolution is "a mode of evolution in which the only positive agent of change in the whole passage from moner to man is fortuitous variation" (W8: 190). Ananchastic evolution, or evolution by mechanical necessity, consists mainly in the "development under the pressure of external circumstances" (W8: 199), such as natural catastrophes, as is suggested for instance by Clarence King. In other words, we speak of ananchasm for every theory that attributes "all progress to an inward necessary principle, or other form of necessity" (W8: 191).

However, before moving to the account of agapasm, it is worthwhile to note that even in this essay Peirce does not deny the importance and role of chance. It is in this essay in fact where the famous expression "chance begets order" (W8: 190) is found. Thus, far from repudiating chance, Peirce calls into question the fact that it is the only "positive agent" of growth and evolution. As he states: "In genuine agapasm [...] advance takes place by virtue of a positive sympathy among the created springing from continuity of mind. This is the idea which tychasticism knows not how to manage." (W8: 195). Accordingly, for Peirce the limit of tychasm, of evolution by chance, is that it fails to give an account of continuity, of sympathy, and of the creative power of love itself. Instead, agapasm does encompass chance, but assigns to it a role subsidiary to the propulsive movement proper to love. 
More in detail, for Peirce tychasm cannot explain the "vital freedom which is the breath of the spirit of love" (W8: 195), or - more in detail - "the bestowal of spontaneous energy by the parent upon the offspring, and, second, [...] the disposition of the latter to catch the general idea of those about it and thus to subserve the general purpose" (W8: 194). From those passages, the profound connection between love and continuity is announced: love and sympathy testify to continuity and represent the only feasible path for continuity to evolve and grow, making something new emerge. Accordingly, we find a new kind of novelty here: one that is not merely coincident with chance but also brought about by continuity, through love. For this reason agape, cherishing love, seems to Peirce the best option for synechism: it is what makes the evolution of a continuous world conceivable. More in detail, Peirce describes this movement of love as circular: "The movement of love is circular, at one and the same impulse projecting creations into independency and drawing them into harmony" (W8: 185). This movement is twofold: on the one hand, it "projects creations into independency," it makes novelties happen, and, on the other hand, it drives them to harmony ${ }^{40}$

Therefore we face two kinds of novelty in Peirce's evolutionary thought. The first one is chance or pure spontaneity, that is, novelty conceived per se, in its own originality and pureness. But there is another kind of novelty in nature: one that is made possible only through the vital continuity of the cosmos. If the common way of understanding continuity is one that excludes novelty or emergence (cf. for instance Goudge 1973), Peirce's concept of continuity, and especially of agapastic evolution, discloses a different possibility. For Peirce, continuous evolution is not subjugated to any mechanical law, and in this sense it can be viewed as open to novelty. But Peirce does not limit it, he goes further when he speaks of the propulsive power of love and agapasm.

Indeed, the fact that agapastic evolution admits and implies chance without recognizing it as the main agency of evolution means that Peirce associates a new "kind of novelty" with creative love, one that is not at all reducible to Firstness. Peirce describes this creative side of agapasm by opposing tychasm to genuine agapasm. He states, "in a genuine agapasm [...] advance takes place by virtue of a positive sympathy among the created springing from continuity of mind" (W8: 195). Thus, it is evident that the advance of the universe is not to be attributed to chance but to sympathy. Chance exists and operates in nature - there is always room for arbitrariness and absolute originality - but what makes the universe grow is this projecting impulse of love, its creative power. Peirce describes sympathy in these pages as surrounding the whole universe.

As a consequence, if he states that "once you have embraced the principle of continuity no kind of explanation of things will satisfy you except that they grew" (CP 1.175, 1893), it must be highlighted that until agapasm is taken into account it is hard to explain how they grow. In this way, Peirce's description of love offers an explanation or at least a hypothesis that explains these indisputable elements of experience and nature, such as growth and novelty. In short, what Chance (Firstness) cannot account for is the kind of novelty that continuity carries with it, that is, "the vital freedom which is the breath of the spirit of love" (W8: 195). This theory of agapastic evolution is really akin to British Emergentism, or at least can be considered as an emergent theory, because it points exactly to that peculiar intertwinement of continuity and novelty that emergence is. In fact, this agapastic view of evolution offers a "positive" description of emergence, that 
is, of how novelty has been brought about. It also offers a new conceptual model for understanding "downward causation," since in Peirce's view Thirdness always implies a "return-effect" on Firstness and Secondness. Indeed, Thirdness needs them to operate without being reducible to them. ${ }^{41}$

A final objection to this hypothesis can be raised and must be addressed: agapism can ultimately be viewed, and is generally viewed, together with Peirce's sharp criticism of Darwin's "Gospel of Greed," as very suggestive, but unfortunately unscientific and hard to support. (1) On the first charge of being too "poetic" or "anthropomorphic," and unscientific, let me reply with Peirce's own words, when he says that:

I hear you say: "All that is not fact; it is poetry." Nonsense! Bad poetry is false, I grant; but nothing is truer than true poetry. [...] Every scientific explanation of a natural phenomenon is a hypothesis that there is something in nature to which the human reason is analogous; and that it really is so, all the successes of science in its application to human convenience are witnesses. They proclaim that truth over the length and breadth of the modern world. (EP2: 193, italics mine, 1903)

(2) With regard to the presumed difficulties in supporting such a position, it seems to me that even a rapid glance at the most recent studies in evolutionary biology ${ }^{42}$ makes us realize how up-to-date Peirce's standpoint is. Without pretending that Peirce's theory is a biological one, and instead considering it a philosophical and conceptual framework within which biological standpoints can be founded and developed, see for instance Martin A. Nowak's theory, which clearly indicates cooperation as the third fundamental principle of evolution, along with mutation and selection (cf. Nowak \& Highfield 2012).

As a conclusion, after this historical and theoretical investigation, we can clearly see how much the "typical emergentist" problem of the relationship between the continuity of evolution and the appearance of novelty lies at the very heart of Peirce's evolutionary hypothesis (namely, agapasm). In this way, apagasm can pave the way for an original, "positive" description of the emergence of novelty, and offers new philosophical and conceptual tools to re-think downward causation, thereby opening new paths of dialogue between philosophy and biology.

\section{BIBLIOGRAPHY}

ALEXANDER Samuel, (1920), Space, Time, and Deity, 2 vols., London, Macmillan.

BAGGIO Guido, (2015), La mente bio-sociale. Filosofia e psicologia in G. H. Mead, Pisa, ETS.

BECKERMAN Ansgar, FLOHR Hans \& Kim JAEGWON, (1992), Emergence or Reduction? Essays on the Prospects of Nonreductive Physicalism, Berlin/New York, De Gruyter.

BEDAU Mark A, (1997), "Weak Emergence," Philosophical perspectives 11 (Mind, Causation and the World), J. E. Tomberlin (ed.), 375-99.

BEDAU Mark A. \& Paul hUMPHREYs, (2008), Emergence: Contemporary Readings in Philosophy and Science, Cambridge (Mass), MIT Press. 
BENNETT-HUNTER Guy, (2015), “Emergence, Emergentism, Pragmatism," Religion and Science, 13 (3), 305-24.

BERNSTEIN Richard, (2010), The Pragmatic Turn, Cambridge (UK), The Polity Press.

BLITZ David, (1992), Emergent Evolution, Dordrecht, Kluwer Academic Publishers.

BROAD Charlie Dunbar, (1925), The Mind and Its Place in Nature, New York/London, Routledge \& Kegan Paul.

BUNGE Mario, (2003), Emergence and Convergence: Qualitative Novelty and the Unity of Knowledge, Toronto, University of Toronto Press.

CARAVÀ Marta, (2015), “La nozione di 'mente estesa' tra scienze cognitive, semiotica e pragmatismo," Rivista Italiana di Filosofia del Linguaggio, 139-51.

CASTON Victor, (1997), "Epiphenomenalisms, Ancient and Modern," The Philosophical Review, 106 (3), 309-63.

CHALMERS David, (2006), "Strong and Weak Emergence," in P. Clayton \& P. Davis (eds), The ReEmergence of Emergence, Oxford, Oxford University Press, 244-55.

CHERLIN Paul B., (2015), "John Dewey's Emergent Naturalism: Conditions and Transfigurations," Contemporary Pragmatism 12, 199-215.

CLAYTON Philip \& Paul C. W. DAVIS (eds), (2006), The Re-Emergence of Emergence, Oxford, Oxford University Press.

CORNING Peter A., (2012), “The Re-Emergence of Emergence, and the Causal Role of Synergy in Emergent Evolution," Synthese, 185 (2), 295-317.

CORRADINI Antonella \& Timothy o'CONNOR (eds), (2010), Emergence in Science and Philosophy, New York, Routledge.

CRANE Tim, (2001), “The Significance of Emergence," in C. Gillett \& B. Loewer (eds), Physicalism and Its Discontents, Cambridge, Cambridge University Press, 207-24.

DEWEY John, (1925), Experience and Nature, London, George Allen \& Unwin.

DEWEY John, (1930), The Quest for Certainty, London, George Allen \& Unwin.

DEWEY John, (1932), "Prefatory Remarks," in G. H. Mead, The Philosophy of the Present, Lasalle, Open Court, xxxvi-xl.

DEWEY John \& Arthur F. BENTLEY, (1949/1989), Knowing and the Known, in J. A. Boydston (ed.), John Dewey: The Later Works, 1925-1953, Carbondale, Southern Illinois University Press, vol. 16, 1-294. DOAT David \& Olivier SARTENAER, (2014), “John Dewey, Lloyd Morgan et l'avènement d'un nouveau naturalisme pragmatico-émergentiste," Philosophiques, 41 (1), 127-56.

EL-HANI Charbel Niño \& Sami PIHLSTRÖM, (2002), "Emergent Theories and Pragmatic Realism," Essays in Philosophy, 3 (2), art. 3. Online: [commons.pacificu.edu/eip/vol3/iss2/3/].

EMERSON Ralph Waldo, (1836), Nature, Boston, James Munroe and Company.

ENGEL Andreas K., FRISTON Karl J. \& Danica KRAGIC, (2016), The Pragmatic Turn Toward Action-Oriented Views in Cognitive Science, Boston, MIT Press.

FABBRICHESI Rossella, (2016), "Peirce, Mead and the Theory of Extended Mind." Online: [commens.org/encyclopedia/article/fabbrichesi-rossella-peirce-mead-and-theory-extendedmind]. 
FISCH Max, (1954), “Alexander Bain and the Genealogy of Pragmatism," Journal of the History of Ideas, 15 (3), 413-44.

GALLAGHER Shaun, (2017), Enactivist Interventions: Rethinking the Mind, Oxford, Oxford University Press.

GILLETT Carl \& Barry LOEWER (eds), (2001), Physicalism and Its Discontents, Cambridge, Cambridge University Press.

GOUDGE Thomas A., (1973), "Pragmatism's Contribution to an Evolutionary View of Mind," The Monist, 57 (2), 133-50.

HACKING Ian, (1983), "Nineteenth Century Cracks in the Concept of Determinism," Journal of the History of Ideas, 44 (3), 455-75.

HEMPEL Carl G. \& Paul OPPENHEIM, (1948), "Studies in the Logic of Explanation," Philosophy of Science, $15(2), 135-75$.

HENNING Brian G., MYERS William T. \& Joseph D. JOHN, (2015), Thinking with Whitehead and the American Pragmatists: Experience and Reality, Lanham, Lexington Book.

HWANG Philip H., (1993), "Peirce and Aristotle on Chance," in E. C. Moore (ed.), Peirce and the Philosophy of Science, University of Alabama Press, 262-75.

JAMES William, (1911), Some Problems of Philosophy, London, Longsman, Green, and co.

KAUFFMANN Stuart A., (2019), A World Beyond Physics. The Emergence and Evolution of Life, New York, Oxford University Press.

KIM Jaegwon, (1999), “Making Sense of Emergence," Philosophical Studies 95, 3-36.

KIM Jaegwon, (2006), “Emergence: Core Ideas and Issues,” Synthese, 151 (3), 547-59.

MADZIA Roman \& Matthias JUng (eds), (2015), Pragmatism and Embodied Cognitive Science, Berlin/ Boston, De Gruyter.

MAYR Ernst, (2005), What Makes Biology Unique?, Cambridge, Cambridge University Press.

MCLAUGHLin Brian P., (1992), "The Rise and Fall of British Emergentism," in A. Beckermann, H. Flohr \& J. Kim (eds), Emergence or Reduction? Essays on the Prospects of Nonreductive Physicalism, Berlin/New York, De Gruyter, 49-93.

MEAD George Herbert, (1932), The Philosophy of the Present, LaSalle, Open Court. METZ Rudolph, (1938), A Hundred Years of British Philosophy, New York, Macmillan.

MORGAN C. Lloyd, (1913), “Spencer's Philosophy of Science," in Herbert Spencer lectures. Decennial issue, 1905-1914, Oxford, Clarendon Press, 1916, 3-53.

MORGAN C. Lloyd, (1923), Emergent Evolution, London, Williams and Norgate.

MURPHY Arthur E., (1932), "Introduction," in G. H. Mead, The Philosophy of the Present, LaSalle, Open Court, xi-xxxvi.

NOWAK Martin \& Roger HIGHFIELD, (2012), Supercooperators, New York, Free Press.

NUBIOLA Jaime, (2001), "Peirce on Complexity," in W. Schmitz (ed.), "Processes in Complex Systems." Proceedings of the 7th International Congress of the IASS-AIS, Thelem, Dresden, 11-23.

O'CONNOR Timothy, (1994), “Emergent Properties,” American Philosophical Quarterly, 31 (2), 91-104. 
PARRAVICINI Andrea, (2012), Il pensiero in evoluzione: Chauncey Wright tra darwinismo e pragmatismo, Pisa, Edizioni ETS.

PEIRCE Charles Sanders, (1787-1951), Charles S. Peirce Papers, MS Am 1632, Houghton Library, Harvard University. [R refers to the manuscripts as listed in Richard Robin. 1967. Annotated Catalogue of the Papers of Charles S. Peirce. Amherst, University of Massachusetts Press. Citations of the form "R \# CSP \#" refer to Peirce's own pagination; citations of the form "R \# ISP \#" refer to the numbers stamped in 1974 on each sheet of a copy of the microfilm edition of the Harvard manuscripts (The Charles S. Peirce Papers, Cambridge, Harvard University Library, 1966, 33 reels) and kept at the Institute for Studies in Pragmaticism, Texas Tech University, Lubbock, TX.] [R] PEIRCE Charles Sanders, (1889-1891), “Entries," in Whitney William D. (ed.) (1889-1891), Century Dictionary and Cyclopedia, New York, The Century Company. Online: [global-language.com/ CENTURY].

PEIRCE Charles Sanders, (1931-1958), Collected Papers of Charles Sanders Peirce, vols. 1-6, eds. Charles Hartshorne \& Paul Weiss (1931-1935); vols. 7 \& 8, ed. Arthur W. Burks (1958). Cambridge, MA, Harvard University Press. [CP]

PEIRCE Charles Sanders, (1975-1979), Charles Sanders Peirce: Contributions to “The Nation," vols. 1-4, eds. K. L. Ketner \& J. E. Cook, Lubbock, Texas Tech Press. [N]

PEIRCE Charles Sanders, (1976), The New Elements of Mathematics by Charles S. Peirce, 4 vols., ed. by C. Eisele, The Hague, Mouton. [NEM] PEIRCE Charles Sanders, (1982-present), Writings of Charles S. Peirce: A Chronological Edition, ed. Peirce Edition Project, Bloomington, IN, Indiana University Press. [W]

PEIRCE Charles Sanders, (1992), Reasoning and the Logic of Things, ed. Kenneth Laine Ketner, Cambridge (MASS), Harvard University Press. [RLT]

PEIRCE Charles Sanders, (1992-1998), The Essential Peirce: Selected Philosophical Writings, 2 vols. Vol. 1, eds. Nathan Houser \& Christian Kloesel (1992); vol. 2, ed. Peirce Edition Project (1998).

Bloomington, IN, Indiana University Press. [EP]

PIHLSTRÖM Sami, (2002), “The Re-Emergence of the Emergence Debate," Principia, 6 (x) 133-81.

PUTNAM Hillary, (1999), The Threefold Cord: Mind, Body, World, New York, Columbia University Press.

QUIEROZ João \& Charbel Niño EL-HANI, (2006), "Semiosis as an Emergent Process," Transactions of the Charles S. Peirce Society, 42 (1), 76-116.

REYNOLDS Andrew, (2002), Peirce's Scientific Metaphysics, Nashville, Vanderbilt University Press. ROSE Philip, (2016), “C. S. Peirce's Cosmogonic Philosophy of Emergent Evolution: Deriving Something from Nothing," Scio: Revista de Filosofia 12, 123-42.

SAWYER Keith R., (2002), "Emergence in Psychology: Lessons from the History of Non-Reductionist Science," Human Development 45, 2-28.

SCHILLER Ferdinand Canning Scott, (1921-22), "The Presidential Address," Proceedings of the Aristotelian Society 22, 1-22.

SCHILLER Ferdinand Canning Scott, (1930), “Creation, Emergence, Novelty," Proceedings of the Aristotelian Society. New Series 31, 25-36.

SEIDEL Marc-David L. \& Henrich R. GREVE, (2017), Emergence: How Novelty, Growth, and Formation Shape Organizations and Their Ecosystems, Bingley (UK), Emerald Group Publishing. 
SKAGESTAD Peter, (1979), “C. S. Peirce on Biological Evolution and Scientific Progress,” Synthese, 41 (1), 85-114.

SMYTH Richard, (1985), "Peirce's Examination of Mill's Philosophy," Transactions of the Charles S. Peirce Society, 21 (2), 157-99.

STEPHAN Achim, (1992), "Emergence - A Systematic View of Its Historical Facets," in

A. Beckermann, H. Flohr \& J. Kim (eds), Emergence or Reduction? Essays on the Prospects of Nonreductive Physicalism, Berlin/New York, De Gruyter, 25-48.

STEPHAN Achim, (1999), Emergenz: Von der Unvorhersagbarkeit zur Selbstorganisation, Dresden/ München, Dresden University Press.

TIERCELIN Claudine, (1998), "Peirce's Objective Idealism. A Defense," Transactions of the Charles S. Peirce Socitety, 34 (1), 1-28.

TOMASEllo Michael, (2009), Why We Cooperate, Boston, MIT Press.

viola Tullio, (2016), “Peirce on Abduction and Embodiment," in R. Madzia \& M. Jung (eds), Pragmatism and Embodied Cognitive Science, Berlin/Boston, De Gruyter, 251-68.

WEST Stuart A., GRIFFIN Ashleigh S. \& Andy GARDNER, (2007), "Evolutionary Explanations for Cooperation," Current Biology 17, R 661-72.

WHITEHEAD Alfred N., (1929/1979), Process and Reality, corrected edition by David Ray Griffin and Donald W. Sherburne, New York, Free Press.

WHITNEY William D. (ed.), (1889-1891), Century Dictionary and Cyclopedia, New York, The Century Company. Online: [global-language.com/CENTURY].

WIENER Philip P., (1949), Evolution and the Founders of Pragmatism, Cambridge, Harvard University Press.

zHок Andrea, (2011), Emergentismo, Pisa, Edizioni ETS.

\section{NOTES}

*. This research was founded by the Department of Philosophy "Piero Martinetti" of the University of Milan under the Project "Department of Excellence 2018-2022" awarded by the Ministry of Education, University and Research (MIUR).

1. Cf. C.S. Peirce, R 408, CSP 173; CP 7.467, 1893. In the cited passage the author defines every concept as the "the living influence of a diagram or an icon, with whose parts are connected in thought an equal number of feelings or ideas."

2. Cf. Kauffman 2019; Seidel \& Greve 2017; Corradini \& O'Connor 2010; Bedau \& Humphreys 2008; Clayton \& Davis 2006; Pihlström 2002; Kim 1999; Stephan 1999; Beckerman, Flohr \& Kim 1992.

3. Added by me, in line with Bennett-Hunter's previous paragraphs.

4. A third possibility can be added in this regard, that of "nominal emergence," that refers to the general properties of a system or a complex totality. Thus, with nominal emergent phenomena we refer to a "macro" property, as opposed to a "micro" property. Due to the rare adoption of this concept in current debates, I will not take it into account (Cf. Corradini \& O'Connor 2010: 48-51).

5. Bedau \& Humphreys (2008: 5). Among the first supporters of the epistemological conception of emergence see Hempel \& Oppenheim 1948.

6. Bunge (2003: 14). 
7. I adopt the very general word "phenomena" to indicate everything we can call "emergent." Another key problem of emergentist debates is indeed whether "emergent" are substances, or qualities, properties, entities, processes, etc.

8. Cf. Bedau (1997: 375-99).

9. Cf. Kim (1999: 20-4). The following list is my synthesis of the claims pointed out by Kim. S and $\mathrm{W}$ indicates if strong (S) or weak (W) emergence supports the tenet described.

10. Samuel Alexander is actually Australian-born. Furthermore, even if Rudolph Metz in A Hundred Years of British Philosophy affirmed that Lloyd Morgan and Alexander were the first recognized as founders of British Emergentism (cf. Metz 1938: 653-62), the three of them are currently recognized as the British Emergentism's exponents (cf. especially Stephan 1992; McLaughlin 1992).

11. This period corresponds to the third (of fourth) phases of the history of emergentism pinpointed by Stephan: "I call this rather long period the third phase: it starts in 1926 where at the "Sixth International Congress of Philosophy" theories of emergence were on the rampage getting their own section with lectures by Hans Driesch, "Emergent Evolution," Arthur O. Lovejoy, "The Meanings of 'Emergence' and its Modes," and W. M. Wheeler, "Emergent Evolution and the Social." In the same year the Aristotelian Society organized a symposium on "The Notion of Emergence." Speakers were E. S. Russell, C. R. Morris and W. L. Mackenzie. Stephen C. Pepper's article "Emergence" was published the same year. In the following decade W. T. Stace, "Novelty, Indeterminism, and Emergence" (1939), P. Henle, "The Status of Emergence" (1942), and G. Bergmann, "Holism, Historicism, and Emergence" (1944) discussed the notion of emergence in consideration of the presumably related concepts of novelty and non-predictability. Even the articles of C. W. Berenda, "On Emergence and Prediction" (1953), and A. Pap, "The Concept of Absolute Emergence" (1952) belong to the third phase. The discussion of emergence came to a temporary end with the work of C.G. Hempel and P. Oppenheim, "Studies in the Logic of Explanation" (1948), and E. Nagel, The Structure of Science (1961)” (Stephan 1992: 26).

12. If we consider also pragmatism outside of the US, Schiller should also be mentioned. $\mathrm{Cf}$. the following paragraph.

13. James is often cited in their works, from the Principles and later works. In Alexander's Space, Time and Deity, he is especially referred to in relation to Alexander's investigation of categories, to spatial and temporal relations, the concept of mind and its connection to bodily actions, and even his notion of "novelty," a pivotal concept for emergentism (cf. Alexander 1920 vol. i: xx, 94, 107, 113, 116-8, 165-7, 238-9, 247-9; vol. ii: 193, 323-4, 342, 376-8, 407, 423; Lloyd Morgan 1923: xii, 74 - those are quotations of James's "The Meaning of Truth" -, in addition we should also consider James's influence on Lloyd Morgan as psychologist; Broad 1925: 118-20 on James's "evolutionary argument" on the action of mind on body and 558, 571 on the unity of the self).

14. On the relation between pragmatism and emergentism from a historical perspective see especially Stephan (1999: 134-8); El-Hani \& Pihlström 2002; Pihlström 2002; Sawyer 2002; Doat \& Sartenaer 2014; Baggio 2015.

15. As for Dewey, Schiller also has a critical approach to the notion of emergence. He recognizes its role and function but does not accept it due to its ambiguity. Cf. the following paragraph and footnote 14 .

16. Together with "emergentism," Murphy also quotes A. N. Whitehead and his speculation, both epistemological and metaphysical, together with some theories of relativity. With this regard, Alfred North Whitehead can be properly indicated as the mediating figure between British Emergentism and classical pragmatists, that is, Dewey and above all Mead (cf. Mead 1932; Henning, Myers \& John 2015).

17. Roughly speaking, to characterize their "emergentism," we may say that Mead's emergentism is distinguishable for its social and linguistic characteristics, since he focuses on the social and linguistic character of the self. In a nutshell, for Mead the self emerges from the social structure, 
as well as from language (cf. Mead 1932, 1934). Dewey's emergentism, instead, is basically connoted by a theory of meaning and action as emergent from the dynamical interplay of environment and subjects (Dewey 1925).

18. Besides, of course, they did make use of the concept of emergence. Goudge specifies: "Dewey and Mead used the category of emergence. Its negative function was to resist the classical thesis that (1) since mental phenomena now exist, they must have been implicitly or potentially present in evolution from the very start; and (2) their potential presence played an active part in their later realization, and was not merely an abstract possibility. Both constituents of the classical thesis, according to Dewey, are gratuitous assumptions which can be avoided if we take seriously the continuous cumulative nature of any developmental process, for example, growth from infancy to maturity." (Goudge 1973: 142).

19. For the same reason, a "pragmatic turn" (Bernstein 2010; Engel, Friston \& Kragic 2016) has recently been identified in philosophy of mind and cognitive sciences. Indeed, against the traditional representational view of cognition, a new action-oriented paradigm has been privileged in the last decade, and the theories of inactive and extended mind, together with embodied cognition, are without doubt the closest to pragmatism. Cf. especially Madzia \& Jung 2015; Caravà 2015; Fabbrichesi 2016; Viola 2016; Gallagher 2017.

20. Under the strong influence of Henri Bergson, cf. footnote 21.

21. Schiller states:"[W]e have tonight to consider the most detested of subjects, which runs odiously counter to every instinct and every habit of every being, animate and inanimate. Even a desperado like myself would hardly have dared to intrude it upon a gathering of respectable philosophers, if he could not quote precedents and claim support; if, that is, the greatest of living metaphysicians had not so effectively pleaded for a revision of the old Eleatic verdict, to which nearly all philosophers have assented with such uncritical docility and unthinking enthusiasm, that no place need be made for Novelty in our philosophies, because Novelty is as such ultimately unthinkable and impossible. Perhaps M. Bergson's greatest achievement is to have shaken this prejudice, and to have made Novelty a good philosophic problem. It is no longer mere impertinence to inquire into Novelty, to ask philosophers to recognize its existence, to beg them to analyse why they hate it and won't, and to insist that, whether they hate it or not, they have got to have it. [...] Novelty is ineluctable and we are all so constructed as to experience it, and the world is continually generating it, it may be more reasonable, or at least more sensible, to try to understand it than to try to ignore it." (Schiller 1921-22: 1-2). With reference to novelty, Alfred North Whitehead also had a crucial role for the place assigned to novelty in his philosophy and cosmology. Indeed, he declares in Process and Reality (1929) that the ultimate of his philosophy is "creativity," defined as "the principle of novelty" (Whitehead 1929 [1979]: 21).

22. More in detail, Chapter IX is entitled "The Problem of Novelty," and there the issue of novelty is introduced, in connection to some major topics: perception, science, personal experience and the infinite; Chapter X, "Novelty and the Infinite - The Conceptual View," scrutinizes discontinuity and continuity theories, in particular Zeno's, Kant's and Renouvier's views; Chapter XI, "Novelty and the Infinite - The Perceptual View," undertakes an analysis of the new concept of the infinite and investigates the perceptual experience of novelty and its conceptual consequences"; similarly, Chapter XII and XIII ("Novelty and Causation - The Conceptual View," "Novelty and Causation - The Perceptual View") analyze novelty and causation both from a conceptual perspective and a perceptual one; the former chapter takes into account the concepts of causality of Aristotle, Scholastics, Occasionalism, Leibniz, Hume, Kant, Positivism, and deductive theories; and the latter tackles the perceptual experience of causation, with reference to the arising of novelties.

23. For a more detailed analysis of pragmatism (both classical and contemporary) on emergentism cf. El-Hani \& Pihlström (2002: 26-32); Stephan (1999: 134-8).

24. Quoted in El-Hani \& Pihlström (2002: 28). 
25. However, Bain is clearly not explicitly mentioned here.

26. For J. S. Mill, Peirce's interest in his logic and scientific methodology, as well as the latter's criticism of Mill's nominalism, is clearly stated from the sixties onwards (cf. for instance the Harvard Lecture on Whewell, Mill, Compte in 1865, but more generally all the occurrences present in both Writings and manuscripts. Very significant is also how Peirce understood the connection/opposition between Mill and Darwin (cf. EP2: 158, 1903). For a critical examination on Mill and Peirce see Smyth 1985. For Bain we face a similar situation, given the massive presence of references in Peirce's opus. Probably his most notorious influence is on the concept of the pragmatic maxim. Cf. for instance R 325, Pragmatism made easy, (unav.es/gep/ PragmatismMadeEasy.html), transcribed by Juan Pablo Serra: "The particular point that had been made by Bain and that had most struck Green, and through him, the rest of us, was the insistence that what a man really believes is what he would be ready to act upon, and to risk much upon," and cf. overall Fisch 1954. The only exception in terms of Peirce's acquaintance is probably Lewes, although his work, Problems of Life and Mind is quoted just after Peirce's entry on "emergent year" in the Century dictionary (Peirce 1889-1891: 1897). Besides, Peirce not only quoted Lewes's work on Aristotle in his lectures on British Logicians (W2: 315, 1869), but carefully considers Lewes's standpoint in his "Grand Logic" (cf. R 400, CSP 45, 1893-95), quoting from the first volume of Lewes's Problems of Life and Mind.

27. We will tackle again these two elements in the following paragraph, where we will consider in detail Peirce's view of evolution, namely agapasm. On Spencer's account see Blitz (1992: 24-34); and (ibid.: 94-5) on Lloyd Morgan and Spencer.

28. Cf. Wiener (1949, Chapter 3), and Parravicini 2012.

29. Since Peirce's approach to Darwin is highly "logical," I think that a question may naturally arise: to what extent does what Peirce said about Darwin really refer to Darwin's thought? Indeed, we might think that the American philosopher is far from the real contents of Darwin's thought, but - if we extend our consideration to recent developments of evolutionary biology, or at least to the modern synthesis, we will surprisingly discover that Peirce was much closer to the mark than we would have expected. With this regard consider that Ernst Mayr, one of the leading exponents of the modern synthesis, in explaining why the "usual physicalist ideas" are not applicable to biology, emphasizes how, from Darwin onwards, biology needs (1) to abandon essentialism and typological thinking, (2) to dismiss deterministic laws and accept the absence of universal laws (in biology), and 3) to reject physicalist reductionism (cf. Mayr 2005: 27).

30. For a more detailed analysis of the relevance of tychism for Peirce see the last paragraph (\$4). 31. In this regard, it is worthwhile to note how Peirce underlines as primary the logical soundness of his standpoint. He wrote after the quoted passage: "The superior logic of my view appears to me not easily controverted." (W8: 122, 1891).

32. Cf. also Peirce's Lowell Lectures on the History of Science (1892) and the "Reply to the Necessitarians" (1893).

33. Although such statements do not appear strange today, in the 19th century they are very uncommon. After relativity, quantic physics, and more broadly after the flourishing of autocritical reflections by scientists in the 20th century, we are indeed quite accustomed to the "relative" and "historical" side of science. But, at that time, by emphasizing these aspects, Peirce was breaking with the past and with the philosophical tradition. Cf. for instance what Emerson states in Nature, though the power of chance also receives considerable attention in his philosophy: "Any distrust of the permanence of laws, would paralyze the faculties of man. Their permanence is sacredly respected, and his faith therein is perfect. The wheels and springs of man are all set to the hypothesis of the permanence of nature." (Emerson 1836: 48).

34. On the connection between evolution, natural laws as mechanical, and fallibilism cf. also R 955 CSP 37, CP 1.174, c. 1893: "Evolution means nothing but growth in the widest sense of that word. Reproduction, of course, is merely one of the incidents of growth. And what is growth? Not 
mere increase. Spencer says it is the passage from the homogeneous to the heterogeneous - or, if we prefer English to Spencerese - diversification. [...] And yet mechanical law, which the scientific infallibilist tells us is the only agency of nature, mechanical law can never produce diversification." And R 1274a, ISP 8, 1892: "If all things result from evolution then law must be conceived as such a result. But a law which is in process of development is not absolute. Therefore, thoroughgoing evolutionism is essentially \& unavoidably hostile to necessitarianism, as the doctrine that all events are necessary a precise result of law."

35. Indeed my investigation is limited to the concept of "emergent evolution," and I did not take into account, for instance, the emergence of mind.

36. Peirce refers to the "Gospel of Greed" as the general "conviction of the nineteenth century is that progress takes place by virtue of every individual's striving for himself with all his might and trampling his neighbor under foot whenever he gets a chance to do so" (W8: 189).

37. A phrase that, after all, belongs to Spencer and not to Darwin.

38. I chose to focus especially on Evolutionary Love because in my view it represents the best place where the complexity of Peirce's standpoint on evolution appears, and where we can understand more clearly how Peirce's concept of evolution tries to keep together continuity and creativity, or novelty.

39. For an introductory definition of synechism: "Materialism is the doctrine that matter is everything, idealism the doctrine that ideas are everything, dualism the philosophy which splits everything in two. In like manner, I have proposed to make synechism mean the tendency to regard everything as continuous." (CP 7.565, c.1892); one of the most eminent examples in this regard is the new synechistic conception of world and mind. Peirce states: "We naturally make all our distinctions too absolute. We are accustomed to speak of an extend universe and an inner world of thought. But they are merely vicinities with no real boundary between them." (R 400, CSP 78-79, 1893-95).

40. The second part is connected to the function of habit, another indispensable element of Peirce's agapasm, though it cannot substitute the propulsive energy of love. Indeed, the force of habit is what makes the novelty effective, giving a certain direction to it. Cf. in this regard Peirce's clear-cut disambiguation when speaking of Lamarck: W8: 192-3. I will not consider Peirce's references to Lamarck, not because I overlook them, but because they need a full, separate, extensive analysis.

41. As Peirce underlines in 1898: “[...] I chiefly insist upon continuity, or Thirdness, and in order to secure to Thirdness its really commanding function, I [find it indispensable] that is a third, and that Firstness, or chance, and Secondness, or Brute reaction, are other elements without the independence of which Thirdness would not have anything upon which to operate." (R 948, RLT, $261,1898)$.

42. Cf. Nowak \& Highfield 2012, but also West, Griffin \& Gardner 2007, and Tomasello 2009.

\section{ABSTRACTS}

The present paper proposes an emergentist reading of Peirce, with special reference to his concept of evolution. Although the author never adopts the word "emergence" in a technical manner, it will be demonstrated that the core problem of emergence lies at the heart of his evolutionary doctrine, generally displayed by the interplay of his three well-known categories of Firstness, Secondness and Thirdness. Indeed, although the Classical pragmatists most quoted in 
connection to emergentism are Dewey and Mead (and William James to some degree), scholars have recently suggested some emergentist readings of Peirce's thought (cf. above all Tiercelin 1998, Quieroz \& El-Hani 2006, Rose 2016), in particular with regard to semiotic process and cosmogony. Exploring further the path opened by those researches, the present paper aims to clarify the theoretical problem of emergent evolution from a pragmatist perspective and especially to illustrate Peirce's emergentist standpoint. In order to reach this goal, the article is divided into four parts: after (1) a brief introduction to the contemporary debates on emergence, (2) I give a historical overview of Classical Pragmatism and British Emergentists, (3) with a special focus on the common roots of the British Emergentists and Peirce on evolution. Finally, (4) I offer an emergentist reading of Peirce's theory of evolution. In particular, I show how his strong emphasis on chance and the "growth" of the universe go together with his arch-stone of synechism (that is his theory of continuity), through what he calls agapasm.

\section{AUTHOR}

\section{MARIA REGINA BRIOSCHI}

Università degli Studi di Milano

mariaregina.brioschi[at]gmail.com 